Eskişehir Osmangazi Üniversitesi

Sosyal Bilimler Dergisi

Nisan 2019, 20 (Özel Sayı), sayfa aralığı

DOI: 10.17494/ogusbd.

\title{
Dönüşüm Geometrisi Öğretiminde 5E Öğrenme Modelinin 7. Sınıf Öğrencilerinin Van Hiele Dönü- şüm Geometrisi Düşünme Düzeylerine Etkisi*
}

\author{
Özgül DEMIR, Aytaç KURTULUŞ** \\ Dönüşüm Geometrisi Öğretiminde $5 E$ Öğrenme \\ Modelinin 7. Sınıf Öğrencilerinin Van Hiele Dönüşüm \\ Geometrisi Düşünme Düzeylerine Etkisi
}

Özet

$\mathrm{Bu}$ çalışmada, 7. Sınıf dönüşüm geometrisi öğretiminde, $5 E$ modelinde gerçekleştirilen eylem araştırmasının, öğrencilerin Van Hiele dönüşüm geometrisi düşünme düzeylerinin gelişimine etkisini ortaya koymak amaçlanmaktadır. Araştırma 7. Sınıf öğrencilerinden oluşan 28 kişilik bir sınıfla gerçekleştirilmiştir. Dönüşüm geometrisi konusu, 4 hafta süreyle, $5 E$ modeline uygun hazırlanan eylem planlarına göre işlenmiştir. Uygulama öncesinde öğrencilere Van Hiele Dönüşüm Geometrisi Düşünme Düzeyleri Testi (VHDGDDT) uygulanmış, buna göre eylem planları oluşturulmuştur. Uygulama sürecinde 7. Sınıf öğretim programına uygun olarak eş şekiller, öteleme, yansıma ve ötelemeli-yansıma konularını içeren çalışma yaprakları hazırlanmış ve uygulanmıştır. Uygulama süreci sonunda öğrencilere, VHDGDDT uygulama sonrası testi olarak uygulanmıştır. VHDGDDT'nin öğrenci bazında uygulama öncesi ve uygulama sonrası düzey karşılaştırması yapılmıştır. Sonuçlar, dönüşüm geometrisi öğretiminde $5 E$ modelinde gerçekleştirilen eylem planlarının, öğrencilerin Van Hiele dönüşüm geometrisi düşünme düzeylerini arttırdığını göstermiştir.

Anahtar Kelimeler: 5E Modeli, Dönüşüm Geometrisi, Van Hiele Modeli, Dönüşüm Geometrisi Düşünme Düzeyleri

\author{
The Effect Of $5 E$ Learning Model on 7th Grade Students' \\ Van Hiele Transformation Geometry Levels in Teaching \\ Transformation Geometry
}

Abstract

In this study, it is aimed to reveal the effect of the action research conducted based on $5 \mathrm{E}$ model on the development of students Van Hiele transformation geometry thinking levels in the teaching of $7^{\text {th }}$ grade transformation geometry. The research was conducted with a class constituted of $287^{\text {th }}$ grade students. The subject of transformation geometry was processed the action plans prepared according to $5 \mathrm{E}$ model for 4 weeks. Van Hiele Transformation Geometry Thinking Levels Test (VHTGTLT) was applied to the students before the application and action plans were prepared accordingly. During the application process, work sheets containing congruent figures, translation, reflection, translation-reflection subjects were prepared and applied according to the $7^{\text {th }}$ grade curriculum. At the end of the application process, VHTGTLT was applied as a post action test. VHTGTLT was compared to pre action and post action levels on the student basis. The results have shown that the action plans prepared in compliance with $5 \mathrm{E}$ learning model in transformation geometry teaching have increased the students' Van Hiele transformation geometry levels of thinking.

Key Words: 5E Model, Transformation Geometry, The Van Hiele Model, Transformation Geometry Thinking Levels

\section{Giriş}

Bilim ve teknoloji çağı olarak adlandırdığımız bir dönemde yaşanan gelişmeler matematiğin önemini ortaya koymaktadır. Bugün matematiği anlayan ve matematik yapabi-

*Bu araştırma 1. yazarın yazmış olduğu ve 2. yazarın danışmanlığında yürütülmüş olan Yüksek Lisans tezinden üretilmiştir. **Özgül DEMiR, Öğretmen., Geyve Cumhuriyet Ortaokulu, ozguldemir34@gmail.com, ORCID ID orcid.org / 0000-0003-07841083, Aytaç KURTULUŞ, Prof. Dr.,Eskisehir Osmangazi Üniversitesi, Eğitim Fakültesi, Matematik ve Fen Bilimleri Eğitimi Bölümü, agunaydi@ogu.edu.tr, ORCID ID orcid.org / 0000-0003-2397-3510 
len toplumlar geleceklerin şekillenmesine yön verirken, matematikten uzak kalan toplumlar gelecekte yaşanan gelişmelere de uzak kalacaklardır (NCTM, 2000, s. 50)

Matematik gerçeği tanımlamanın, bilgiyi düzenlemenin ve dünyayı anlamanın bir yoludur. Galileo'nun bir sözünde belirttiği gibi “Doğanın kanunları matematiğin dilinde yazılmıştır". Bugün bu dili anlayan ve akıcı bir şekilde konuşanlar dünyadaki önemli gelişmelere yön vereceklerdir. Bu düşünce toplumların matematiğe verdikleri önemi arttırmış, eğitim-öğretim programlarında yenilenme ve değişmeyi sağlamıştır. Bu program değişiklikleri öğrencinin bilgiye kendisinin ulaşabileceği ve bilgiyi kendisinin yapılandırabileceği, öğrenci merkezli bir anlayışla yapılmıştır. Bu kapsamda ülkemizde matematik dersi öğretim programları 2005 yılında yapılan değişikliklerle geliştirilmiş ve programda yeni alt öğrenme alanlarına yer verilmiştir. Bu alt öğrenme alanlarından biri olan, "öteleme", "yansıma”, "dönme" ve “ötelemeli-yansıma” konularını içeren dönüşüm geometrisi cisimlerin hareketlerini inceler.

Dönüşüm geometrisi bir nesnenin görüntüsünü oluşturabilmek için nesnenin şeklinde ve uzunluklarında değişiklik yapmadan hareket ettirilmesi işlemini içerir. Öteleme, dönme ve yansıma gibi dönüşümlerde şeklin kenar uzunlukları aynı kalır, sadece konumu değişir. Ortaokul matematik öğretim programında yer almasa da genişleme gibi dönüşümlerde, şeklin kenar uzunluklarında da değişiklik olur. Dönüşüm geometrisi, geometri dersinde öğrencilerin iki boyutlu düşünme becerisini geliştirerek onların uzamsal ve yaratıcı düşünmelerini destekler. Dönüşüm geometrisi sayesinde öğrenciler iki boyutlu uzayda şekilleri nasıl dönüştürebileceklerini ve bazı kuralları ve şekillerin özelliklerini keşfederler (Ince, 2012, s. 17).

Öğrencilerin şekilleri dönüştürebilecekleri hareketlerden biri olan öteleme, bir şeklin bir düzlem boyunca kaydırılması işlemini içerir. Temel olarak öteleme şeklin sadece konumundaki değişikliktir. Yansıma şeklin bir simetri doğrusuna göre çevrilmesi hareketidir. Bu hareket sonucunda oluşan şeklin görüntüsü, orijinal görüntüsüne göre terstir. Dönme hareketi şeklin bir nokta etrafında belirli bir açıyla saat yönünde ya da saatin tersi yönünde döndürülmesidir. Etrafında şekli döndürdüğümüz nokta, dönme merkezi olarak adlandırılır. Dönme merkezi şeklin üzerinde ya da dışında olabilir. Ötelemeli-yansıma ise ardışık ötelemeler ve yansımalar sonucu şeklin hareket ettirilmesi işlemini içerir. Şeklin ötelendikten sonra yansıtılması ile yansıtıldıktan sonra ötelenmesi sonucu oluşan görüntüsü birbirine eştir. Bu dönüşümlerden öteleme, yansıma ve ötelemeli-yansıma ile ilgili kazanımlar 2013 yılı ortaokul matematik dersi öğretim programında, 7. Sınıf kazanımları içerisinde yer alırken; dönme ve koordinat sisteminde dönüşümler 8. Sınıf programında yer almaktadır. Bu kazanımlar verilirken öğrencilerin geometrik düşünme düzeylerine uygun bir öğretim yapılması öğretim etkililiğini arttıracaktır. 
Geometrik düşünme modellerinden biri olan Van Hiele modeli öğrencilerin geometrik düşünme düzeylerini dikkate alan bir modeldir. Bu model öğrencilerde geometrik düşünme becerisinin hiyerarşik sıralanmış beş düzeyden geçtiğini savunan bir anlayışa dayanır. Bu düzeyler görselleştirme basamağı olan 1. Düzey, analiz basamağı olan 2. Düzey, informal çıkarım basamağı olan 3. Düzey, çıkarım basamağı olan 4. Düzey ve sistematik düşünme düzeyi olan 5. Düzeyden oluşur. Bu düzeylerin artmasında bireylerin yaşadığı deneyimler önemli olup, düzeylerin sağladığı beceriler ile dönüşüm geometrisi düşünme düzeyleri de artar. Dönüşüm geometrisi düşünme düzeyleri, Soon (1989) tarafından Van Hiele geometrik düşünme düzeyleri analiz edilerek tanımlanmıştır (Akt., Kurak, 2009, s. 23). Burada çalışmanın gerçekleştirildiği grup ortaokul öğrencileri olduğundan ilk 3 düzeye yer verilmiştir.

Dönüşüm Geometrisi Düşünme Düzeyleri ve Düzeylerin Özellikleri

1. Düzey

- Öğrenci şekildeki değişiklikleri gözlemleyerek dönüşümü tanımlar.

- Öğrenci dönüşümleri isimlendirir ya da standart ve standart olmayan isimler kullanır.

Bu özellikler, öğrencinin şekil ve hareketteki değişiklikleri gözlemleyerek dönüşümü fark ettiğini gösterir.

2. Düzey

- Öğrenci dönüşümlerin meydana getirdiği değişikliklerden yola çıkarak dönüşümün özelliklerini fark eder.

- Dönüşümler ve dönüşümlerin özellikleri ile ilgili tanımlamalarda bulunur.

- Koordinat sistemini kullanarak dönüşümleri birbirleriyle ilişkilendirebilir.

- Öğrenci yansımanın simetri eksenini, ötelemenin öteleme vektörünü ve dönme hareketinin dönme merkezini konumlandırabilir.

- Öğrenci dönüşümlerin özelliklerini kullanarak problem çözebilir.

Bu özellikler, öğrencinin şekil ve imgelerde gözlemlediği değişikliklerin özelliklerini kullanarak dönüşümleri tanımladığını ve isimlendirdiğini gösterir.

3. Düzey

- Öğrenci, basit dönüşümleri bir arada kullanabilir. lendirir.

- Şeklin, başlangıç ve son durumlarından yola çıkarak dönüşümleri isim-

- Şeklin, başlangıç ve son durumlarını kullanarak, uygulanan dönüşümü basit dönüşümlerin kompozisyonu olarak ayrıştırır ve birleştirir.

- Dönüşümleri, koordinatları kullanarak tanımlar.

Bu özelliklerden hareketle, öğrencilerin dönüşümlerin özelliklerini birbirleriyle ilişkilendirdiği söylenebilir. 
Ülkemizde 2013 yılında ortaokul matematik dersi öğretim programı yapılandırmacı yaklaşım temelinde yeniden düzenlenmiştir. Bu yaklaşıma dayalı yöntemler de aktif olarak matematik öğretiminde kullanılmaya başlanmıştır. Matematik öğretiminde kullanılan bu yöntemlerden biri olan, öğrencileri ileri seviyede düşünmeye teşvik eden ve öğrenciler için dersi ilgi çekici hale getiren 5E öğrenme modeli Jean Piaget ve John Dewey'in araştırmaları kapsamında Rodger Bybee tarafından geliştirilmiştir. Öğrencilerdeki araştırma merakını artıran ve öğrenci beklentilerine uygun, bilgi için gerekli beceri ve aktiviteleri içeren bu model kalıcı ve derinlemesine bir öğrenme gerçekleştirilmesine olanak tanır. $5 \mathrm{E}$ öğrenme modeli adını döngüyü oluşturan basamakların baş harfinden almıştır. 5E öğrenme modeli basamaklarına Şekil 1.1'de yer verilmiştir.

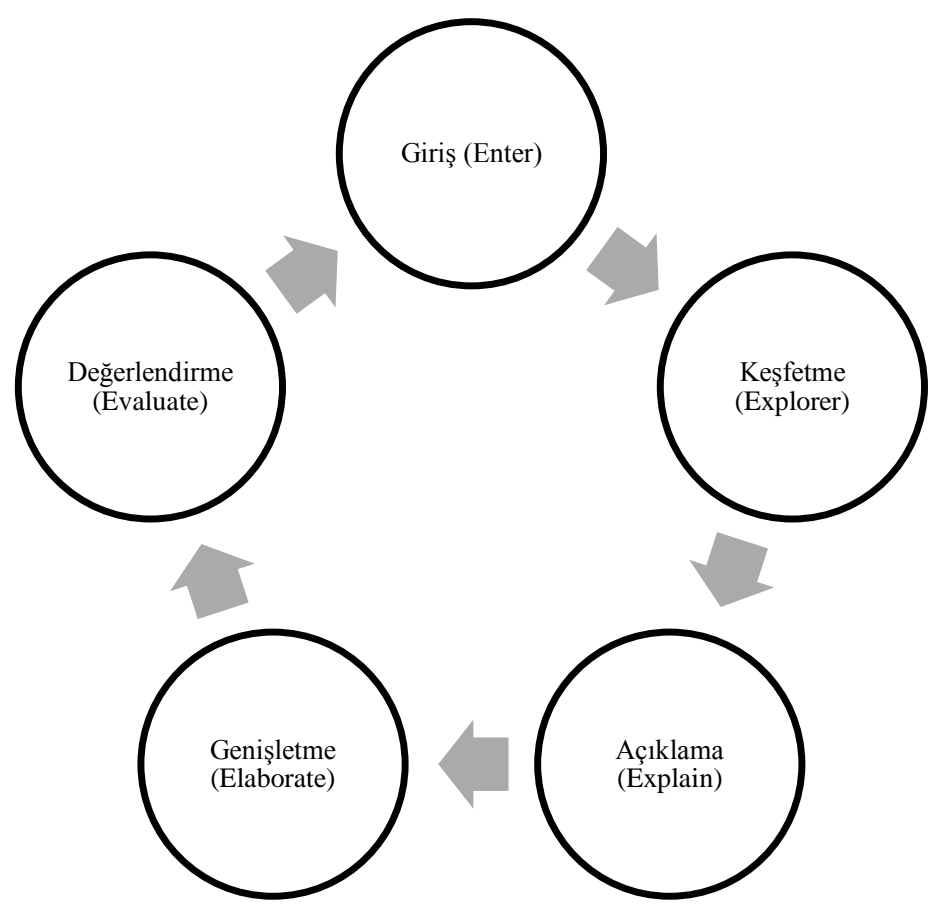

Şekil 1.5E Öğrenme Modeli Basamakları

Bu basamaklar; öğrencinin ilgisinin çekildiği giriş basamağı, öğrencilerin deneyler yaparak aktif katılım sağladıkları keşfetme basamağı, öğrencilerin yaptıkları deneylerin sonuçlarını açıkladığı ve öğretmenin geribildirimlerde bulunduğu açıklama basamağı, öğrencilerin süreç içerisinde öğrendikleri bilgi ve becerileri uyguladıkları derinleştirme basamağı 
ve öğrencilerin süreç boyunca öğrendiklerinin değerlendirildiği değerlendirme basamağıdır. $5 E$ öğrenme modeli her basamakta öğrenciyi merkeze alarak bilgiyi keşfetmesini ve bilgiyi anlamlandırmasını sağlar. Ortaokul matematik öğretim programı da bu anlayışı temele almaktadır.

5E öğrenme modelinin Fen Bilimleri alanında etkililiğini ortaya koyan birçok çalışma olmasına rağmen matematik alanında yapılan çalışmaların yetersiz olduğu görülmektedir. Matematikte bu alanda yapılan çalışmalar, trigonometri, karmaşık sayılar, birinci dereceden bir bilinmeyenli denklemler, çember, daire, silindir konularıyla sınırı kalmış ya da diğer geometri konularıyla birlikte ele alınmıştır. $5 \mathrm{E}$ öğrenme modeline uygun olarak yapılan öğretimin Van Hiele geometrik düşünme düzeylerine etkisinin araştırıldığı tek çalışma Yıldız'ın (2014) açılar, çokgenler ve dönüşüm geometrisi konularının öğretimi üzerine yaptığı çalışmadır. Yapılan bu çalışmayla, ortaokul matematik öğretim programı 7. Sınıf dönüşüm geometrisi konusunun öğretiminde $5 \mathrm{E}$ öğrenme modelinde gerçekleştirilen eylem araştırmasının öğrencilerin Van Hiele dönüşüm geometrisi düşünme düzeylerine etkisi araştırılarak literatürde bulunan eksikliğin giderilmesine katkı sağlayabileceği düşünülmektedir.

\section{Yöntem}

Bu çalışma nitel araştırma yöntemlerinden eylem araştırması kullanılan kapsamlı bir araştırmanın bir bölümünü oluşturmaktadır. Araştırmayla doğrudan ilgisi bulunan kişilerce yapılan eylem (aksiyon) araştırması bu çalışmanın yöntemi olarak belirlenmiştir. Watts'e göre, eylem araştırmaları, araştırmacıların farklı araştırma teknikleri yardımıyla kendi eğitim uygulamalarını, sistematik bir şekilde inceledikleri bir süreçtir (Akt. Ferrance, 2000, s. 1). Eylem araştırmalarında izlenen yollar literatürde farklıık göstermektedir. Bu araştırmada Ferrance'nin (2000, s. 9) Eylem Araştırması Döngüsü esas alınmıştır. Şekil $2.1^{\prime}$ de bu aşamalara yer verilmiştir. 


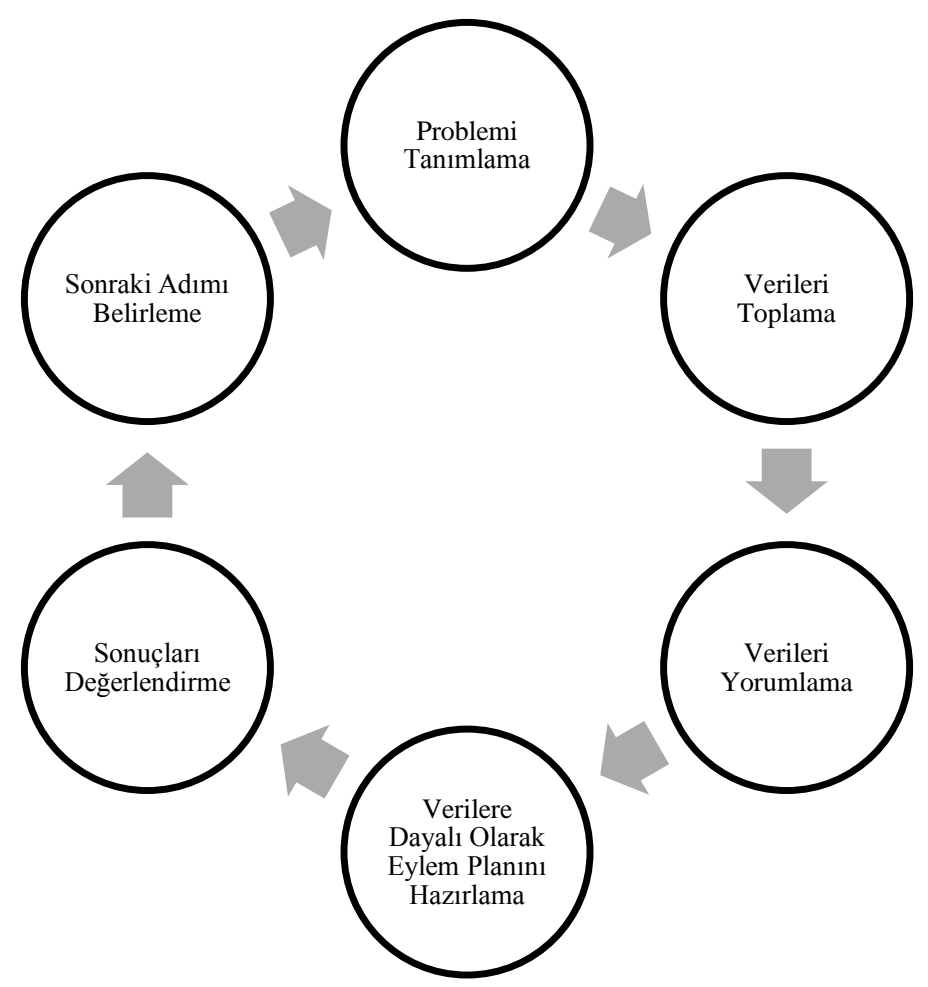

Şekil 2. Eylem Araştırması Döngüsü

Şekil 2.1'deki döngünün ilk aşaması problemi tanımlama aşamasıdır. Problem tanımlanıp ortaya konulduktan sonra yapılacak diğer adım verilerin toplanmasıdır. Toplanan veriler yorumlanarak anlamlı hale getirilir. Eldeki verilere uygun eylem planları hazırlanır. Hazırlanan planlar uygulandıktan sonra sonuçlar değerlendirilir. Eğer bu aşamada planların içeriğiyle ilgili bir problem varsa düzeltme ya da geliştirme yoluna gidilir. Son olarak yapılacak sonraki adımlar belirlenir.

\subsection{Araştırmanın Uygulama Süreci}

Bu çalışmada, 7. Sınıf dönüşüm geometrisi öğretiminde, 5E modelinde gerçekleştirilen eylem araştırmasının, öğrencilerin Van Hiele dönüşüm geometrisi düşünme düzeylerinin gelişimine etkisini ortaya koymak amaçlanmaktadır. Bu amaçla öncelikle öğrencilerin Van Hiele dönüşüm geometrisi düşünme düzeyleri belirlenmiştir. Araştırma 7. Sınıf matematik öğretim programında yer alan "eş şekiller, öteleme ve yansıma" dönüşüm geometrisi konularıyla sınırlı tutulmuştur. Öğretim için planlanan uygulama süreci matematik 
öğretim programında belirtilen 20 ders saati ile sınırlı kalınarak öğrencilere sunulmuştur. Uygulama süreci 4 eylem planı ile yürütülmüştür. Bu eylem planları $5 \mathrm{E}$ öğrenme modelinin aşamalarına uygun olarak hazırlanmış ve uygulanmıştır.

1. Eylem Planında eş şekiller üzerinde çalışılmıştır. Eş şekiller konusunun yansıma, öteleme ve ötelemeli-yansıma konuları için önkoşul oluşturduğu söylenebilir. Eş şekiller konusuna ait kazanıma uygun olarak 5E Modelinin giriş, keşfetme, açıklama, derinleştirme ve değerlendirme aşamalarına yer verilmiştir. 1. Eylem Planı değerlendirilerek öğrenci eksiklikleri ve hataları tespit edilmiş, etkinliklerin işlevselliği ve yeterliği belirlenmiş buna göre 2. Eylem Planı hazırlanmıştır.

2. Eylem Planında öteleme üzerinde çalışılmıştır. Öteleme konusuna ait kazanımlara uygun olarak 5E Modelinin giriş, keşfetme, açıklama ve derinleştirme aşamalarına uygun etkinlikler planlanmıştır. 2. Eylem Planı değerlendirildiğinde bazı etkinliklerin fazla olduğu görülmüş, öğrenci eksiklikleri tespit edilmiş ve etkinlik sayısı düşürülerek öğrenci eksikliklerini gidermeye yönelik yeni etkinlikler hazırlanarak 3. Eylem Planı hazırlanmıştır.

3. Eylem Planında yansıma konusu üzerinde çalışılmıştır. Yansıma konusuna ait kazanımlara uygun olarak 5E Modelinin giriş, keşfetme, açıklama ve derinleştirme aşamalarına yer verilmiştir. 3. Eylem Planı değerlendirildiğinde öteleme ve yansıma konularında öğrenci eksikliklerinin görülmediği, bu konulara ilişkin anlaşılmayan bir nokta olmadığı, etkinliklerin yeterli olduğu sonucuna ulaşılmış, 4. Eylem Planı buna göre oluşturulmuştur.

4. Eylem Planında ötelemeli-yansıma konusu üzerinde çalışılmıştır. Ötelemeliyansıma konusuna ait kazanımlara uygun olarak $5 \mathrm{E}$ öğretim modelinin derinleştirme ve değerlendirme aşamalarına yer verilmiştir. Giriş, keşfetme ve açıklama aşamaları öğrencilerden gelen talepler doğrultusunda, çok fazla etkinliğin öğrencilerin derse olan ilgilerini kaybetmelerine neden olduğu gerekçesiyle plandan çıkarılmış, eylem planının son haline yer verilmiştir. Uygulama süreci sonunda eylem araştırmasının öğrencilerin Van Hiele dönüşüm geometrisi düşünme düzeylerinin gelişimine etkisini ortaya koymak amacıyla Van Hiele dönüşüm geometrisi düşünme düzeyleri testi yeniden uygulanmıştır.

\section{2. Çalışma Grubu}

Araştırmanın katılımcılarını 2015-2016 eğitim-öğretim yılında İstanbul ilinde bir ortaokulda öğrenim görmekte olan 7. Sınıf öğrencileri oluşturmaktadır. Tüm etkinlikler 15 erkek, 13 kız öğrenciden oluşan toplam 28 öğrenciden oluşan bir 7. Sınıfta uygulanmıştır. Araştırmanın çalışma grubunu oluşturan öğrencilerin adları yerine kod adlarına yer verilerek katılımcıların gizliliği konusuna dikkat edilmiştir. Araştırmanın bulgular bölümünde bu kodlar kullanılmıştır. 


\section{Özgül DEMiR | Aytaç KURTULUŞ}

\subsection{Veri Toplama Araçları}

Eylem araştırmasında veriler hem nicel hem de nitel yöntemlerle toplanabilir. Bu araştırmada veri toplama aracı olarak 14 açık uçlu sorudan oluşan Van Hiele Dönüşüm Geometrisi Düşünme Düzeyleri Testi ve araştırmacı günlüğü kullanılmıştır.

Dönüşüm geometrisi konusunda öğrencilerin Van Hiele dönüşüm geometrisi düşünme düzeylerini belirlemek için Soon (1989) tarafından geliştirilen ve Kurak (2009) tarafından düzenlenerek oluşturulan 14 soruluk Van Hiele Dönüşüm Geometrisi Düşünme Düzeyleri Testi kullanılmıştır. Testte, 1. Düzeyde verilen dönüşüm hareketlerini tanımlamaya yönelik 3 soru (1,2,3. sorular), 3. Düzeyde dönüşüm hareketlerinin özellikleri ile ilgili işlemler yapmayı gerektiren 7 soru $(4,5,6,7,8,9,10$. sorular) ve 3 . Düzeyde dönüşüm hareketinin özelliklerini birbirleriyle ilişkilendirmeye yönelik 4 soru $(11,12,13,14$. sorular) olmak üzere toplam 14 soru bulunmaktadır. Bu testte yer alan soruların düzeylere ve konulara göre dağılımları Tablo 2.1'de verilmiştir.

Tablo 1.Van Hiele Dönüşüm Geometrisi Düşünme Düzeyleri Testinde Yer Alan Soruların Düzeylere ve Konulara Göre Dağılımları

\begin{tabular}{lcccc}
\hline \hline & Öteleme & Yansıma & Dönme & Ardışık Dönüşümler \\
\hline Düzey-1 & $1 \mathrm{c}, 2 \mathrm{c}, 3 \mathrm{~b}$ & $1 \mathrm{a}, 2 \mathrm{a}, 3 \mathrm{c}$ & 1b, 2b, 3a & \\
Düzey-2 & $6 \mathrm{c}, 7 \mathrm{a}, 9$ & $4,6 \mathrm{a}, 7 \mathrm{~b}, 8$ & 6b, 7c, 10 & 5 \\
Düzey-3 & 13 & 11 & 14 & 12 \\
\hline
\end{tabular}

Araştırmalarda süreç boyunca yapılan gözlemler, konuya ilişkin yapılabilecek açıklamalar, yorumlar araştırmacı tarafından düzenli olarak not edilir. Bu araştırmada da uygulama öncesi gözlemler; uygulama esnasında öğrenci görüşleri, düşünceleri, yorumları; uygulama sonrası araştırmacının yorumları, önemli gördüğü noktalar araştırmacı tarafından not edilerek araştırmacı günlüğü oluşturulmuştur.

\subsection{Verilerin Analizi ve Yorumlanması}

Van Hiele Dönüşüm Geometrisi Düşünme Düzeyleri Testi'ne öğrencilerin verdikleri cevaplar analiz edilirken Usiskin (1982)'in geliştirdiği test için geometri düzeyin belirlenmesinde düzeyle ilgili 5 sorudan en az 3 soruyu doğru kuralı uygulanmıştır. Buna göre, öğrencinin 1. Düzey için sorulan 3 sorudan 2'sini doğru cevaplaması, 2. Düzey için 7 sorudan 4'ünü doğru cevaplaması ve 3. Düzey için 4 sorudan 3'ünü doğru cevaplaması gerekir (Akt. Kurak, 2009, s. 44). Öğrenci bu araştırmada 1. Düzeye geçebilmesi için gereken ilk 3 sorudan 2'sini doğru yanıtlayamamışsa diğer düzeyler için yeterli sayıda doğru cevap vermişse bile 0 . Düzey olarak kabul edilmiştir. 
Bu araştırmada Van Hiele Dönüşüm Geometrisi Düşünme Düzeyleri Testi'ni oluşturan sorular ve sorulara verilen yanıtların betimsel analizleri yapılmıştır. Betimsel analiz Yıldırım ve Şimşek (2003)'ün belirttiği gibi dört aşamada gerçekleşmektedir. Birinci aşamada araştırmanın kavramsal çerçevesini oluşturan Van Hiele Dönüşüm geometrisi düşünme düzeylerinin özeliklerinden hareket edilerek veri analizi için bir çerçeve oluşturulmuştur. Bu yolla veriler Van Hiele Dönüşüm geometrisi düşünme düzeylerinin özelikleri temaları altında düzenlenmiş ve sunulmuştur. İkinci aşamada açık uçlu sorulardan oluşan Van Hiele Dönüşüm geometrisi düşünme düzeyleri testine öğrencilerin verdiği cevaplardan elde edilen veriler belirlenen temalar çerçevesinde değerlendirilerek düzenlenmiş ve üçüncü aşama için bulgular tanımlanmıştır. Son aşamada bulgular ilişkilendirilerek açıklanmıştır (Yıldırım ve Şimşek, 2003). Daha sonra öğrencilerin Van Hiele Dönüşüm Geometrisi Düşünme Düzeyleri Testi'nden elde ettikleri sonuçlar çalışma öncesi-çalışma sonrası testi olarak karşılaştırılarak yüzde frekans olarak verilmiştir.

Araştırmacı günlüğünden elde edilen veriler, çalışmanın nitel verilerinin açıklanması aşamasında kullanımıştır. Öğrencilerin uygulama öncesi, uygulama esnası ve uygulama sonrasında yapılan tüm işlemlerde belirttiği görüşler, düşünceler, fikirler, nedenler, sonuçlar ve araştırmacının araştırmanın her aşamasında gözlemlediği davranışlar nitel verilerin yorumlanması aşamasında değer kazanmış, eksik noktalar bu veriler sayesinde aydınlatılmıştır.

\section{Bulgular}

Bu bölümde uygulamanın öğrencilerin Van Hiele dönüşüm geometrisi düşünme düzeylerine etkisine yönelik bulgulara yer verilmiştir.

Öğrencilerin Van Hiele dönüşüm geometrisi düşünme düzeylerini belirlemek için Van Hiele Dönüşüm Geometrisi Düşünme Düzeyleri Testi çalışma öncesi testi olarak uygulanmıştır. 4 hafta boyunca 7. Sınıf dönüşüm geometrisi öğretiminde 5E öğrenme modeline uygun tasarlanan eylem planlarıyla uygulama süreci yapıldıktan sonra öğrencilerin Van Hiele dönüşüm geometrisi düşünme düzeylerinde artış olup olmadığını belirlemek amacıyla Van Hiele Dönüşüm Geometrisi Düşünme Düzeyleri Testi çalışma sonrası testi olarak uygulanmıştır. Çalışma öncesi test ile çalışma sonrası testten elde edilen sonuçlar öğrencilerin sorulara verdikleri cevaplara göre düzey olarak Tablo 3.1'de sunulmuştur. 
Tablo 2. Van Hiele Dönüşüm Geometrisi Düşünme Düzeyleri Testi Çalışma ÖncesiÇalışma Sonrası Sonuçları

\begin{tabular}{ccc}
\hline \hline Öğrenciler & $\begin{array}{c}\text { Van Hiele DGDDT } \\
\text { Çalışma Öncesi Düzey- } \\
\text { leri }\end{array}$ & $\begin{array}{c}\text { Van Hiele DGDDT } \\
\text { Çalışma Sonrası Düzeyleri }\end{array}$ \\
\hline $\begin{array}{c}\text { Ö1, Ö4, Ö8,Ö9, } \\
\text { Ö19, Ö20 }\end{array}$ & 1 & 2 \\
\hline Ö2, Ö7, & 0 & 1 \\
\hline $\begin{array}{c}\text { Ö3, Ö6, Ö14, } \\
\text { Ö15, Ö18, Ö23 }\end{array}$ & 1 & 3 \\
\hline Ö5 & 0 & 2 \\
\hline $\begin{array}{l}\text { Ö10, Ö12, Ö21, } \\
\text { Ö26, Ö27, Ö28 }\end{array}$ & 2 & 3 \\
\hline Ö11 & 0 & 3 \\
\hline $\begin{array}{l}\text { Ö13, Ö16, Ö17, } \\
\text { Ö22, Ö2 }\end{array}$ & 1 & 3 \\
\hline Ö24 & 3 & \\
\hline
\end{tabular}

Van Hiele DGDDT

Not. Van Hiele DGDDT: Van Hiele Dönüşüm Geometrisi Düşünme Düzeyleri Testi

Tablo 3.1 incelendiğinde Van Hiele Dönüşüm Geometrisi Düşünme Düzeyleri Testi’ne verdikleri cevaplara göre; düzeyi aynı kalan 8 öğrenci, düzeyi artan 20 öğrencinin olduğu görülür. Elde edilen sonuçlara göre düzeyi düşen öğrenci olmamıştır. Bu sonuçların $5 \mathrm{E}$ öğrenme modeline uygun olarak hazırlanan eylem planlarının öğrencilerin Van Hiele dönüşüm geometrisi düşünme düzeylerini artırdığı söylenebilir. Öğrencilerin çalışma öncesi ve çalışma sonrası testlerinden elde ettikleri düzeyler yüzde oranlarıyla birlikte Tablo 3.2' de verilmiştir.

Tablo 3. Öğrencilerin Van Hiele Dönüşüm Geometrisi Düşünme Düzeyleri Testi'nden Elde Ettikleri Düzeylerin Dağılımı

\begin{tabular}{cccccc}
\hline \hline & & \multicolumn{2}{c}{$\begin{array}{c}\text { Çalışma Öncesi } \\
\text { Sonuçlar }\end{array}$} & \multicolumn{2}{c}{ Çalışma Sonrası Sonuçlar } \\
& $\begin{array}{c}\text { Van Hiele Dönüşüm } \\
\text { Geometrisi Düşünme } \\
\text { Düzeyleri }\end{array}$ & $\begin{array}{c}\text { Sayı } \\
\text { (N) }\end{array}$ & $\begin{array}{c}\text { Yüzde } \\
\text { (\%) }\end{array}$ & $\begin{array}{c}\text { Sayı } \\
\text { (N) }\end{array}$ & $\begin{array}{c}\text { Yüzde } \\
\text { (\%) }\end{array}$ \\
\hline Çalışma Grubu & 0. Düzey & 4 & 14,28 & 1 & 3,57 \\
Öğrencileri & 1. Düzey & 17 & 60,69 & 8 & 28,56 \\
& 2. Düzey & 6 & 21,42 & 7 & 24,99 \\
& 3. Düzey & 1 & 3,57 & 12 & 42,84 \\
\hline
\end{tabular}


Tablo 3.2'deki çalışma öncesi ve çalışma sonrası düzeyler karşılaştıııldığında; 0. Düzeyde olan öğrenci sayısında uygulama sonrasında \%10,71 oranında bir azalma gerçekleşirken, 1. Düzeyde olan öğrenci sayısında ise uygulama sonrası \%32,13 oranında bir azalma gözlenmektedir. 2. Düzeyde olan öğrenci sayısında uygulama sonrasında \%3,57 oranında bir artma gerçekleşirken, 3. Düzeyde olan öğrenci sayısında uygulama sonrasında $\% 39,27$ oranında bir artma olduğu gözlenmektedir.

Dört hafta boyunca 7. Sınıf dönüşüm geometrisi konularının öğretimi 5E öğrenme modeline uygun olarak hazırlanan eylem planlarıyla gerçekleştirildikten sonra öğrencilerin Van Hiele Dönüşüm Geometrisi Düşünme Düzeyleri Testi'ndeki 1., 2. ve 3. Düzey sorulara verdikleri cevaplar ilişkili olduğu düzeyin özelliklerine göre analiz edilerek düzey bazında bulgular ayrıntılı olarak verilmiştir.

\subsection{Van Hiele Dönüşüm Geometrisi 1. Düzey Soruların Analizinden Elde Edilen Bulgular}

Öğrencilerin Van Hiele Dönüşüm Geometrisi Düşünme Düzeyleri Testi'ndeki 1. Düzey sorulara verdikleri cevaplar ilişkili olduğu düzeyin özelliklerine göre betimsel olarak analiz edilmiştir. Öğrencilerin Van Hiele Dönüşüm Geometrisi Düşünme Düzeyleri Testi'ne verdikleri cevapların betimsel analiz bulguları ve doğru cevaplarının yüzde oranlarının ilişkili olduğu düzeyin özelliklerine göre dağılımı Tablo 3.3'te verilmiştir.

Tablo 4. Van Hiele Dönüşüm Geometrisi Düşünme Düzeyleri Testi'ndeki 1. Düzey Soruların illişkili Olduğu Düzey Özellikleri

\begin{tabular}{|c|c|c|c|c|c|c|c|}
\hline Düzey & Sorular & & $\begin{array}{l}\text { Sorunun ilişkili Olduğu Düzeyin } \\
\text { Özellikleri }\end{array}$ & Frekans & Yüzde & $\begin{array}{l}\text { Toplam } \\
\text { Frekans }\end{array}$ & $\begin{array}{l}\text { Toplam } \\
\text { Yüzde }\end{array}$ \\
\hline \multirow{6}{*}{$\begin{array}{l}1 . \\
\text { Düzey }\end{array}$} & \multirow[t]{3}{*}{ 1.Soru } & $a$ & $\begin{array}{l}\text { Şekilde meydana gelen değişik- } \\
\text { likler sayesinde yansıma dönü- } \\
\text { şümünü tanımlar. }\end{array}$ & 25 & $\% 89$ & \multirow{3}{*}{25} & \multirow{3}{*}{$\% 89$} \\
\hline & & b & $\begin{array}{l}\text { Şekilde meydana gelen değişik- } \\
\text { likler sayesinde dönme dönü- } \\
\text { şümünü tanımlar. }\end{array}$ & 25 & $\% 89$ & & \\
\hline & & c & $\begin{array}{l}\text { Şekilde meydana gelen değişik- } \\
\text { likler sayesinde öteleme dönü- } \\
\text { şümünü tanımlar. }\end{array}$ & 27 & $\% 96$ & & \\
\hline & \multirow{3}{*}{ 2.Soru } & $a$ & $\begin{array}{l}\text { Şekil ile görüntüsü arasındaki } \\
\text { ilişkiyi belirleyerek yansıma } \\
\text { dönüşümünü isimlendirir. }\end{array}$ & 26 & $\% 93$ & \multirow{3}{*}{25} & \multirow{3}{*}{$\% 89$} \\
\hline & & b & $\begin{array}{l}\text { Şekil ile görüntüsü arasındaki } \\
\text { ilişkiyi belirleyerek dönme dö- } \\
\text { nüşümünü isimlendirir. }\end{array}$ & 21 & $\% 75$ & & \\
\hline & & c & $\begin{array}{l}\text { Şekil ile görüntüsü arasındaki } \\
\text { ilişkiyi belirleyerek öteleme } \\
\text { dönüşümünü isimlendirir. }\end{array}$ & 25 & $\% 89$ & & \\
\hline
\end{tabular}




\begin{tabular}{|c|c|c|c|c|c|c|}
\hline \multirow[t]{3}{*}{ 3.Soru } & $a$ & $\begin{array}{l}\text { Günlük hayatta karşılaşılan } \\
\text { durumlarıniçerdiği dönme dö- } \\
\text { nüşümünü tanımlar. }\end{array}$ & 26 & \%93 & \multirow[t]{3}{*}{27} & \multirow[t]{3}{*}{$\% 96$} \\
\hline & b & $\begin{array}{l}\text { Günlük hayatta karşılaşılan } \\
\text { durumların içerdiği öteleme } \\
\text { dönüşümünü tanımlar. }\end{array}$ & 27 & \%96 & & \\
\hline & c & $\begin{array}{l}\text { Günlük hayatta karşılaşılan } \\
\text { durumların içerdiği yansıma } \\
\text { dönüşümünü tanımlar. }\end{array}$ & 27 & \%96 & & \\
\hline
\end{tabular}

Betimsel analiz ile elde edilen Tablo 3.3'teki bulgulara göre, öteleme, yansıma ve dönme dönüşümlerinin tanımlanmasına ilişkin tüm şıkların, 1. Sorunun doğru yanıtlanma yüzdesine eşit ya da büyük olması dönüşümlerin tanımlanması konusunda öğrencilerin problem yaşamadıklarını gösterir. Bu sonuç, öğrencilerin büyük çoğunluğunun "şekilde meydana gelen değişiklikler sayesinde dönüşümü tanımlar" kazanımına sahip olduklarını göstermiştir.

Tablo 3.3 incelendiğinde, şekil ile görüntüsü arasındaki ilişkiyi belirleyip dönüşümlerin isimlendirilmesine ilişkin şıklardan öteleme ve yansıma, 2. Sorunun doğru yanıtlanma yüzdesine eşit ya da büyük iken, dönme dönüşümünün isimlendirilmesinin 2. Sorunun doğru yanıtlanma yüzdesinden düşük olması öğrencilerin öteleme ve yansımanın isimlendirilmesi konusunda problem yaşamadıklarını ancak dönme dönüşümünü isimlendirirken zorlandıklarını gösterir. Bu sonuç, öğrencilerin büyük çoğunluğunun "şekil ile görüntüsü arasındaki ilişkiyi belirleyerek dönüşümü isimlendirir" kazanımına ulaştıklarını gösterir.

Tablo 3.3 günlük hayatta karşılaşılan durumların içerdiği dönüşümlerin tanımlanmasına ilişkin öteleme, yansıma şıklarının doğru yanıtlanma yüzdesi, 3. Sorunun doğru yanıtlanma yüzdesine eşit iken, dönme dönüşümünü içeren şıkıın doğru yanıtlanma yüzdesinin 3. Sorunun doğru yanıtlanma yüzdesinden küçük olması öğrencilerin günlük hayatta karşılaştıkları durumlarda öteleme ve yansıma dönüşümünü tanımlamakta zorlanmadıkları ancak dönme dönüşümünü tanımlama konusunda zorlandıklarını gösterir. Bu sonuçlar öğrencilerin "günlük hayatta karşılaşılan durumların içerdiği dönüşümleri tanımlar" kazanımına ulaştıklarını gösterir.

1. Düzeyin içerdiği 1,2 ve 3 . Sorulara öğrencilerin ortalama $\% 92$ 'sinin ( $N=26)$ doğru yanıt verdiği Tablo 3.3'te ulaşılan sonuçlar arasındadır. Bu oran 5E öğrenme modeli kullanılarak hazırlanan eylem planları sayesinde öğrencilerin büyük çoğunluğunun 1. Düzeyde dönüşümleri fark ettikleri ve tanımladıklarını göstermektedir. Düzeydeki tüm soruların doğru yanıtlanma oranı bu düzeyin ortalama oranına yakın olduğundan öğrencilerin bu düzeye başarılı bir şekilde geçtiği söylenebilir. 


\subsection{Van Hiele Dönüşüm Geometrisi Düşünmede 2. Düzey Soruların Analizinden El-} de Edilen Bulgular

Öğrencilerin Van Hiele Dönüşüm Geometrisi Düşünme Düzeyleri Testi'ndeki 2. Düzey sorulara verdikleri cevaplar ilişkili olduğu düzeyin özelliklerine göre betimsel olarak analiz edilmiştir. Öğrencilerin Van Hiele Dönüşüm Geometrisi Düşünme Düzeyleri Testi'ne verdikleri cevapların betimsel analiz bulguları ve doğru cevaplarının yüzde oranlarının ilişkili olduğu düzeyin özelliklerine göre dağılımı Tablo 3.4'te verilmiştir.

Tablo 5. Van Hiele Dönüşüm Geometrisi Düşünme Düzeyleri Testi'ndeki 2. Düzey Soruların İlişkili Olduğu Düzey Özellikleri

\begin{tabular}{|c|c|c|c|c|c|c|c|}
\hline Düzey & Sorular & & $\begin{array}{l}\text { Sorunun ilişkili Olduğu Düzeyin } \\
\text { Özellikleri }\end{array}$ & Frekans & Yüzde & $\begin{array}{l}\text { Toplam } \\
\text { Frekans }\end{array}$ & $\begin{array}{l}\text { Toplam } \\
\text { Yüzde }\end{array}$ \\
\hline \multirow{11}{*}{$\begin{array}{l}2 . \\
\text { Düzey }\end{array}$} & 4. Soru & & $\begin{array}{l}\text { Düzlemsel bir şeklin yansıma } \\
\text { sonucu oluşan görüntüsünü } \\
\text { çizer. }\end{array}$ & 18 & $\% 64$ & 18 & $\% 64$ \\
\hline & 5. Soru & & $\begin{array}{l}\text { Görüntüsü verilen şekli ilk hali- } \\
\text { ne getirmek için öteleme ve } \\
\text { dönme hareketlerini uygular. }\end{array}$ & 0 & $\% 0$ & 0 & $\% 0$ \\
\hline & \multirow{3}{*}{ 6.Soru } & $a$ & $\begin{array}{l}\text { Şekil ile görüntüsü verildiğinde } \\
\text { yansıma dönüşümünü isimlen- } \\
\text { dirir. Dönüşümün simetri doğ- } \\
\text { rusunu belirler. }\end{array}$ & 22 & $\% 79$ & \multirow{3}{*}{22} & \multirow{3}{*}{$\% 79$} \\
\hline & & b & $\begin{array}{l}\text { Şekil ile görüntüsü verildiğinde } \\
\text { dönme dönüşümünü isimlendi- } \\
\text { rir. Dönüşümün dönme merke- } \\
\text { zini belirler. }\end{array}$ & 14 & $\% 50$ & & \\
\hline & & C & $\begin{array}{l}\text { Şekil ile görüntüsü verildiğinde } \\
\text { öteleme dönüşümünü isimlen- } \\
\text { dirir. Dönüşümün öteleme } \\
\text { vektörünü belirler. }\end{array}$ & 23 & $\% 82$ & & \\
\hline & \multirow[t]{3}{*}{ 7.Soru } & a & $\begin{array}{l}\text { Öteleme dönüşümünün özellik- } \\
\text { lerini bilir. }\end{array}$ & 24 & $\% 85$ & \multirow[t]{3}{*}{22} & \multirow[t]{3}{*}{$\% 79$} \\
\hline & & b & $\begin{array}{l}\text { Yansıma dönüşümünün özellik- } \\
\text { lerini bilir. }\end{array}$ & 24 & $\% 85$ & & \\
\hline & & C & $\begin{array}{l}\text { Dönme dönüşümünün özellikle- } \\
\text { rini bilir. }\end{array}$ & 18 & $\% 64$ & & \\
\hline & \multicolumn{2}{|l|}{ 8. Soru } & $\begin{array}{l}\text { Bir şeklin yansıma dönüşümü } \\
\text { sonucu oluşan görüntüsünün } \\
\text { koordinatlarını belirler. }\end{array}$ & 21 & $\% 75$ & 21 & $\% 75$ \\
\hline & \multicolumn{2}{|l|}{ 9. Soru } & $\begin{array}{l}\text { Bir şeklin öteleme dönüşümü } \\
\text { sonucu oluşan görüntüsünün } \\
\text { koordinatlarını bulabilir. }\end{array}$ & 10 & $\% 36$ & 10 & $\% 36$ \\
\hline & \multicolumn{2}{|l|}{ 10. Soru } & $\begin{array}{l}\text { Şeklin dönme dönüşümü sonu- } \\
\text { cu oluşan görüntüsünün koor- } \\
\text { dinatlarını belirler. }\end{array}$ & 8 & $\% 29$ & 8 & $\% 29$ \\
\hline
\end{tabular}


Betimsel analizden elde edilen Tablo 3.4'te "düzlemsel bir şeklin yansıma sonucu oluşan görüntüsünü çizer" kazanımını içeren 4. Sorunun öğrencilerin yarısından fazlası tarafından doğru yanıtladığı görülür. Öğrencilerin $18^{\prime} i$ çizimi doğru yaparken geri kalan öğrencilerin araştırmacı gözlemlerine göre yansıma sonucu şeklin kenar uzunlukları ve açılarının ölçülerinin değişmediğini bildikleri ancak gereken önemi vererek doğru ve hassas çizim yapamadıkları için soruyu doğru yanıtlayamadıkları kabul edilmiştir. Tablo 3.4'e göre öğrencilerin yarısından fazlasının "düzlemsel bir şeklin yansıma sonucu oluşan görüntüsünü çizer" kazanımına sahip oldukları söylenebilir.

Tablo 3.4 incelendiğinde "görüntüsü verilen şekli ilk haline getirmek için öteleme ve dönme hareketlerini uygular" kazanımını içeren 5. Soruyu öğrencilerin hiçbirinin doğru yanıtlayamadığı görülür. Öğrenciler sorunun içerdiği öteleme hareketini yapmış ancak dönme hareketini gerçekleştirememişlerdir. 7. Sınıf öğretim programı dönme dönüşümüne yer vermediğinden öğrenciler ardışık öteleme ve dönme gerektiren bu soruyu doğru yanıtlamakta başarısız oldukları söylenebilir.

Tablo 3.4'e göre şekil ile görüntüsü verildiğinde dönüşümü isimlendirme kazanımında öteleme ve yansıma dönüşümünü içeren şıkların doğru yanıtlanma yüzdesi 6 . Sorunun doğru yanıtlanma yüzdesinden fazla iken, dönme dönüşümünü isimlendirme şıkkının doğru yanıtlanma yüzdesinin 6 . Sorunun doğru yanıtlanma yüzdesinden küçük olması öğrencilerin şekil ile görüntüsü verildiğinde öteleme ve yansımayı isimlendirebildikleri ancak dönme dönüşümünü isimlendirme ve dönme merkezini belirleme konusunda zorlandıklarını göstermektedir. Tablo 3.4'e göre öğrencilerin büyük çoğunluğunun "şekil ile görüntüsü verildiğinde dönüşümleri isimlendirir ve öteleme vektörünü, simetri doğrusunu belirler" kazanımında başarıya ulaştıklarını gösterirken dönme merkezini belirleyebilme kazanımında öğrencilerin yarısının başarılı olamadıklarını görülmektedir.

Tablo 3.4 incelendiğinde dönüşümlerin özelliklerini bilme konusunda öteleme ve yansıma şıklarının doğru yanıtlanma oranı 7. Sorunun doğru yanıtlanma oranından fazla iken, dönme şıkkının doğru yanıtlanma oranının sorunun doğru yanıtlanma oranından düşük çıkması öğrencilerin öteleme ve yansıma dönüşümünün özelliklerini iyi bildikleri ancak dönme dönüşümünün özellikleri konusunda zorlandıklarını gösterir. Bu sonuçlar, öğrencilerin çoğunun özelikle öteleme ve yansıma dönüşümlerinde "dönüşümlerin özelliklerini bilir" kazanımına ulaştıklarını gösterir. Bir önceki paragrafta elde edilen bulgu ile ilişkilendirildiğinde dönme dönüşümünde belirli bir açı kadar döndürüldüğünü bilmesine rağmen dönme dönüşümünün dönme merkezini belirleme özeliğinde daha çok zorlandıkları söylenebilir.

Tablo 3.4'te "bir şeklin yansıma dönüşümü sonucu oluşan görüntüsünün koordinatlarını belirler" kazanımını içeren 8. Sorunun öğrencilerin büyük çoğunluğu tarafından 
doğru yanıtlandığı görülür. Bu sonuç, öğrencilerin "şeklin yansıma sonucu oluşan görüntüsünün koordinatlarını oluşturur" kazanımına ulaştıklarını gösterir.

Tablo 3.4'te "bir şeklin öteleme dönüşümü sonucu oluşan görüntüsünün koordinatlarını bulabilir" kazanımına yönelik 9. Sorunun öğrencilerin 10'u tarafından doğru yanıtlandığı görülür. Bu sonuç, $5 \mathrm{E}$ öğrenme modeline uygun olarak hazırlanan eylem planlarının, öğrencilerin öteleme dönüşümünü tanımlamalarına ve dönüşümlerin özelliklerini bilmelerine katkı sağladığı ancak 7. Sınıf öğretim programında müfredatında yer almayan dönüşümleri koordinat düzleminde gerçekleştirme kazanımına, öğrencilerin sadece 10'unu ulaştırdığını göstermektedir.

Tablo 3.4 incelendiğinde "şeklin dönme dönüşümü sonucu oluşan görüntüsünün koordinatlarını belirler" kazanımını içeren 10. Sorunun öğrencilerin 8'i tarafından doğru yanıtlandığı görülür. Bu sonuç, 7. sınıf matematik öğretim programı dönüşüm geometrisi konusu içerisinde dönme dönüşümünün öğretimine yer verilmemesi nedeniyle beklenen bir sonuçtur. 8 öğrencinin bu soruya doğru yanıt vermesi $5 E$ öğrenme modeline uygun olarak hazırlanan eylem planlarının şeklin dönme dönüşümü sonucu oluşan görüntüsünün koordinatlarını belirlemeye yardımcı olduğu söylenebilir.

2. Düzeyin içerdiği $4,5,6,7,8,9$ ve 10 . Sorulara öğrencilerin ortalama $\% 52$ 'sinin ( $N=14$ ) doğru yanıt verdiği Tablo 3.4'te ulaşılan sonuçlar arasındadır. Bu sorulara ait oranlardan öteleme ve yansımaya ait olanlar 2. Düzeyin ortalama oranından yüksek iken, dönmeye ait oran bu düzeyin ortalama oranından düşüktür. Bu sonuçlar, 5E öğrenme modeline uygun olarak hazırlanan eylem planları sayesinde ardışık dönüşümler dışında öğrencilerin büyük çoğunluğunun dönüşümlerin özelliklerini bildiklerini göstermektedir. Dönüşümlerin oranlarının düzeyin ortalama oranından yüksek ya da ortalamaya yakın çıkması öğrencilerin 2. Düzeye başarılı bir şekilde geçtiklerini göstermektedir.

\subsection{Van Hiele Dönüşüm Geometrisi Düşünmede 3. Düzey Soruların Analizinden El- de Edilen Bulgular}

Öğrencilerin Van Hiele Dönüşüm Geometrisi Düşünme Düzeyleri Testi'ndeki 3. Düzey sorulara verdikleri cevaplar ilişkili olduğu düzeyin özelliklerine göre betimsel olarak analiz edilmiştir. Öğrencilerin Van Hiele Dönüşüm Geometrisi Düşünme Düzeyleri Testi'ne verdikleri cevapların betimsel analiz bulguları ve doğru cevaplarının yüzde oranlarının ilişkili olduğu düzeyin özelliklerine göre dağılımı Tablo 3.5'te verilmiştir. 
Özgül DEMIR | Aytaç KURTULUŞ

Tablo 6. Van Hiele Dönüşüm Geometrisi Düşünme Düzeyleri Testi'ndeki 3. Düzey Soruların İlişkili Olduğu Düzey Özellikleri

\begin{tabular}{|c|c|c|c|c|c|c|}
\hline Düzey & Sorular & $\begin{array}{l}\text { Sorunun ilişkili Olduğu Düzeyin } \\
\text { Özellikleri }\end{array}$ & Frekans & Yüzde & $\begin{array}{l}\text { Toplam } \\
\text { Frekans }\end{array}$ & $\begin{array}{l}\text { Toplam } \\
\text { Yüzde }\end{array}$ \\
\hline \multirow{4}{*}{$\begin{array}{l}3 . \\
\text { Düzey }\end{array}$} & 11. Soru & $\begin{array}{l}\text { Başlangıç ve son durumları veri- } \\
\text { len şeklin içerdiği yansıma dönü- } \\
\text { şümünü isimlendirir. }\end{array}$ & 15 & $\% 54$ & 15 & $\% 54$ \\
\hline & 12. Soru & $\begin{array}{l}\text { Başlangıç ve son durumlarını } \\
\text { kullanarak, dönüşümü öteleme ve } \\
\text { dönme dönüşümlerinin birleşimi } \\
\text { olarak isimlendirir. }\end{array}$ & 16 & $\% 57$ & 16 & $\% 57$ \\
\hline & 13. Soru & $\begin{array}{l}\text { Başlangıç ve son durumları veri- } \\
\text { len şeklin içerdiği öteleme dönü- } \\
\text { şümünü isimlendirir. }\end{array}$ & 16 & $\% 57$ & 16 & $\% 57$ \\
\hline & 14. Soru & $\begin{array}{l}\text { Başlangıç ve son durumlarını } \\
\text { kullanarak, dönme dönüşümünü } \\
\text { isimlendirir. }\end{array}$ & 8 & $\% 29$ & 8 & $\% 29$ \\
\hline
\end{tabular}

Tablo 3.5 incelendiğinde "başlangıç ve son durumları verilen şeklin içerdiği yansıma dönüşümünü isimlendirir" kazanımını içeren 11. Soruya öğrencilerin yarısından fazlasının doğru yanıt verdiği görülür. Bu sonuç, $5 \mathrm{E}$ öğrenme modeline uygun olarak hazırlanan eylem planları sayesinde öğrencilerin yarısından fazlasının şekil ile görüntüsü arasında ilişki kurarak yansıma dönüşümünün isimlendirmesini sağladığını göstermektedir.

Tablo 3.5'te "başlangıç ve son durumlarını kullanarak, dönüşümü öteleme ve dönme dönüşümlerinin kompozisyonu olarak isimlendirir" kazanımını içeren 12 . Sorunun öğrencilerin yarısından fazlası tarafından doğru yanıtlandığı görülür. Soruyu doğru yanıtlayamayan öğrencilerin verdikleri yanıtlar dikkate alındığında ötelemeyi fark ettikleri ancak dönme yerine bildikleri diğer dönüşüm olan yansımayı kullandıkları görülmüştür. Bu sonuçlar, $5 E$ öğrenme modeline uygun olarak hazırlanan eylem planlarının öğrencilerin dönüşümleri basit dönüşümlerin birleşimi olarak isimlendirmelerini sağladığını ortaya koymuştur.

Tablo 3.5'e bakıldığında "başlangıç ve son durumları verilen şeklin içerdiği öteleme dönüşümünü isimlendirir" kazanımını içeren 13. Sorunun öğrencilerin yarısından fazlası tarafından doğru yanıtlandığı görülür. Bu sonuç, $5 \mathrm{E}$ öğrenme modeline uygun olarak hazırlanan eylem planları sayesinde öğrencilerin yarısından fazlasının şekil ile görüntüsü arasında ilişki kurarak ötelemeyi isimlendirdiğini gösterir.

Tablo 3.5 incelendiğinde "başlangıç ve son durumlarını kullanarak, dönme dönüşümünü isimlendirir" kazanımını içeren 14. Sorunun öğrencilerin 8'i tarafından doğru yanıtlandığı görülür. Öğrencilerin bir kısmının buradaki dönüşümü yansıma ile açıklamaya çaıışması, yansımanın orijine göre olduğunu belirtmediklerinden doğru olarak kabul edilmemiştir. Elde edilen sonuçlar, 5E öğrenme modeline uygun olarak hazırlanan eylem 
planlarının öğrencilerin şekil ile görüntüsü arasında ilişki kurarak dönme dönüşümünü isimlendirme konusunda zorlandıklarını ancak dönüşümü bildikleri bir dönüşüm olan yansıma ile açıklamaya çalışmaları nedeniyle ilişkilendirme konusunda başarı sağladıklarını gösterir.

3. Düzeyin içerdiği $11,12,13$ ve 14 . Sorulara öğrencilerin ortalama \%50'sinin ( $N=14)$ doğru yanıt verdiği Tablo 3.5'te ulaşılan sonuçlar arasındadır. Dönüşümlerden öteleme, yansıma ve ardışık dönüşümlerin doğru yanıtlanma oranı 3. Düzeydeki soruların doğru yanıtlanma oranından fazla iken, dönme dönüşümünün doğru yanıtlanma oranı düzeyin doğru yanıtlanma oranından düşüktür. Bu sonuçlar, $5 \mathrm{E}$ öğrenme modeline uygun olarak hazırlanan eylem planlarının öğrencilerin şekil ve görüntüsü arasında ilişki kurmalarına katkı sağladığını göstermektedir. Öteleme, yansıma ve ardışık dönüşümlerin doğru yanıtlanma oranlarının ortalama orandan yüksek çıkması öğrencilerin 3. Düzeye başarılı bir şekilde geçtiklerini gösterir.

Van Hiele Dönüşüm Geometrisi Düşünme Düzeyleri Testi'nden elde edilen bulgular $5 E$ öğrenme modeline uygun olarak hazırlanan eylem planlarının öğrencilerin Van Hiele dönüşüm geometrisi düşünme düzeylerini arttırdığını ortaya koymaktadır.

\section{Sonuç ve Öneriler}

Bu çalışmada, ortaokul matematik öğretimi programı 7. Sınıf dönüşüm geometrisi konusunun öğretiminde $5 \mathrm{E}$ öğrenme modelin de uygulanan eylem araştırmasının öğrencilerin Van Hiele dönüşüm geometrisi düşünme düzeylerine etkisi incelenmiştir.

$5 E$ öğrenme modeline uygun olarak hazırlanan eylem planlarının öğrencilerin Van Hiele dönüşüm geometrisi düşünme düzeylerine etkisinin araştıııldı̆ı bu çalışmada Soon (1989) tarafından hazırlanan ve Kurak (2009) tarafından düzenlenen “Van Hiele Dönüşüm Geometrisi Düşünme Düzeyleri Testi" başlangıçta, öğrencilerin hazırbulunuşluk düzeyi ile geometrik düşünme düzeylerini belirlemek amacıyla uygulanmıştır. Çalışma öncesi test sonuçlarında öğrencilerin büyük çoğunluğunun "dönüşümleri fark etme ve tanımlama" düzeyi olan 1. Düzeyde kaldıkları elde edilmiştir. Çalışma öncesi testten elde edilen bu sonuç dönüşüm geometrisi konusunda öğrencilerin hazırbulunuşluk düzeylerinin yeterli olmadığı, geometrik düşünme düzeylerinin beklenenden düşük çıktığını ortaya koymaktadır(Soon, 1989). Bu düzeydeki bir öğrencinin deneyimlere bağlı olarak 1. Düzeyden 2. Düzeye geçiş aşamasında olması beklenirken, düzeylerin düşük çıkması matematik öğretim programı çerçevesinde dönüşüm geometrisi konusunda verilen eğitimin gözden geçirilmesini gerekli hale getirmektedir (Bayrak, 2015; Çelebi Akkaya, 2006; Hurma, 2011; Yıldırım, 2009; Yıldız, 2014).

5E öğrenme modeline uygun olarak hazırlanan eylem planlarının 4 hafta boyunca uygulanmasının ardından, Van Hiele Dönüşüm Geometrisi Düşünme Düzeyleri Testi öğrencilere çalışma sonrası testi olarak uygulanmıştır. Çalışma sonrası test sonuçları öğrencilerin ortama düzeylerinin 2 olduğunu gösterirken, öğrencilerin bir kısmının 3. Düzeye 
ulaştıklarını ortaya koymaktadır. Araştırmanın bu bulgusundan hareketle çalışma grubundaki öğrencilerin çalışma sonrasında "dönüşümlerin özelliklerini bilme" düzeyi olan 2 . Düzeye ulaştıkları sonucu çıkarılabilir. Araştırmanın yapıldığı yaş grubu olan ortaokul öğrencilerinin "dönüşümleri fark etme ve tanımlama" düzeyini geçip, "dönüşümlerin özelliklerini bilme" düzeyi olan 2. Düzeyde olmaları beklenmektedir (Van de Walle, Karp ve BayWilliams, 2012, s. 404). Araştırmada öğrencilerin bir kısmının uygulama sonunda dönüşüm geometrisinde ilişkilendirebilme düzeyi olan 3. Düzeye ulaşmaları önemli bir sonuçtur. Araştırmada çalışma öncesi ve çalışma sonrası elde edilen düzeyler incelendiğinde $5 \mathrm{E}$ öğrenme modeline uygun olarak hazırlanan eylem planlarının öğrencilerin beklenen düzeye ulaşmalarını sağladığı görülmüştür. Çalışmadan elde edilen bu sonuç farklı uygulamaların Van Hiele düzeyleri üzerindeki etkililiğini ortaya koyan diğer çalışmalar tarafından da desteklenmektedir (Çelebi Akkaya, 2006; Dağdelen, 2012; Koçak, 2009; Kurak, 2009; Yıldırım, 2009). Van de Walle, Karp ve Bay-Williams (2012) 'e göre düzeylerdeki ilerlemede deneyim önemli olduğuna göre çalışma sayesinde yaşadıkları deneyim öğrencilerin dönüşüm geometrisi başarı düzeylerini arttırdığı söylenebilir.

Van Hiele Dönüşüm Geometrisi Düşünme Düzeyleri Testi'nden elde edilen sonuçlar araştırma temalarına göre incelendiğinde, uygulamanın istenilen kazanımlara ulaşma düzeyine katkı sağladığı görülmektedir. Yapılan uygulamanın öğrencilere "dönüşümleri fark etme ve tanımlama", "dönüşümlerin özelliklerini bilme" ve "dönüşümlerin özelliklerini kullanarak ilişki kurma" becerilerini kazandırdığı söylenebilir. Van Hiele geometrik düşünme düzeyleri üzerinde $5 E$ öğrenme modelinin etkisinin araştırıldığı tek araştırma Yıldız'ın (2014) araştırmasıdır. Yıldız (2014) yaptığı çalışmada 5E öğrenme modeline uygun olarak hazırlanan öğretim etkinliklerine göre gerçekleştirilen eğitimin, öğrencilerin Van Hiele geometrik düşünme düzeylerine olumlu etkisinin olduğunu belirtmiştir. $5 \mathrm{E}$ öğrenme modeline uygun olarak hazırlanan eylem planları yardımıyla işlenen derslerin öğrencilerin düşünme düzeyleri üzerindeki katkılar bu sonuçlar ile sınırlı değildir. Uygulama sürecinde araştırmacı tarafından tutulan notlar ve yapılan gözlemler eylem planlarının içerdiği öğretim etkinliklerinin öğrencilerin derse olan ilgilerini artırdığını da ortaya koymaktadır. Öğrencilerin bu etkinlikler sayesinde daha kolay öğrenebildikleri, ilgilerinin ve motivasyonlarının arttığı, derste daha aktif hale geldikleri görülmüştür. Uygulama esnasında dinamik geometri yazılımlarından GeoGebra'yı kullanmak, Escher süslemeleri yapmak, poster hazırlamak, slowmotion oluşturmak, somut modeller kullanmak, oyunlarla öğrenmek farklı zekâ alanlarına sahip öğrencilerin de derse katılımlarını sağlamış ve matematik yapıyor olma duygusunu kazandırmıştır. Öğrenciler eylem planları sayesinde dönüşüm geometrisi konusunun günlük hayatta hangi alanlarda karşılarına çıkacağını öğrenmiş ve buna göre beklenti oluşturmuşlardır. 5E öğrenme modelinin duyuşsal alanda etkili olduğu yapılan diğer çalışmalarla da desteklenmektedir (Güler, 2010; Gürbüz, 2015; Kaymakçı, 2015; Teltik Başer, 2008; Tomooğlu, 2017; Tuna, 2011). 
Yapılan bu çalışma da 5E öğrenme modeline uygun olarak hazırlanan eylem planları 7. Sınıf matematik öğretim programının dönüşüm geometrisi kazanımlarıyla sınırlı olduğundan planlarda dönme dönüşümüne yer verilmediği halde öğrencilerin uygulama sonunda sezgisel olarak dönme dönüşümünü fark edip tanıyabildikleri ve bir kısmının özeliklerini dahi keşfedebildiği halde bu özelikleri kullanarak dönüşümler arası ilişki kuramadıkları belirlenmiştir. 2009 matematik öğretim programı incelendiğinde dönüşüm geometrisinin yansıma, öteleme, dönme dönüşümlerinin tamamının içerdiği görülmektedir. Oysaki 2013 ve 2016 da düzenlenen matematik öğretim programında kademeli olarak dönüşüm geometrisi kazanımları azaltılırken son olarak 2018 de düzenlenen 1-8 matematik öğretim programında dönme dönüşümünün yer almadığı görülmektedir. Bu durum bazı öğrencilerin dönme dönüşümünde özelik bilme gereken 2. Düzey ve ilişkilendirme gereken 3. Düzeye ulaşmalarında eksikliğe neden olabilir.

Araştırmadan elde edilen bulgulardan yola çıkılarak aşağıdaki öneriler geliştirilmiştir;

- Van Hiele geometrik düşünme düzeyleri üzerinde çeşitli öğretim yöntemlerinin etkisinin araştırıldığı birçok çalışma olmasına rağmen 5E öğrenme modelinin kullanıldığı çalışmalar oldukça sınırlıdır. Farklı planlarla hazırlanan 5E öğrenme modelinin Van Hiele geometrik düşünme düzeyleri üzerindeki etkisinin araştırıldığı çalışmalar gerçekleştirilebilir.

- Mevcut programda dönüşüm geometrisi konuları dönme dönüşümü dışında 7. Sınıf matematik öğretim programında yer almaktadır. 8. Sınıfta da tüm dönüşümlerin koordinat düzlemi üzerinde yapılacak çalışmalara yer verilmektedir. Illkokul dönemlerinde simetri ve dönme kavramlarıyla karşılaşan öğrencilerin ilk defa 7. Sınıfa geldiklerinde öteleme dönüşümüyle karşılaşmaları, öteleme ile birlikte yansıma ve ötelemeli-yansıma konularını görmeleri ancak bu defa da dönmeye yer verilmemesi eksiklik olarak görülmüştür. Van Hiele geometrik düşünme düzeylerine paralel bir matematik öğretim programı oluşturulmalı, dönüşümler düzeylere göre bir bütün olarak ele alınmalıdır.

- Dönüşüm geometrisi üzerine yaptığı çalışmada Soon (1989) öteleme, yansıma, dönme ve ardışık dönüşümlere ilaveten şekillerin belli oranda büyültülmesi ya da küçültülmesi olarak tanımlanan dilation kavramına yer vermiştir. Ülkemizdeki matematik öğretim programında da dönüşüm geometrisi konularına dilation konusu eklenebilir. 
Özgül DEMIR | Aytaç KURTULUŞ

\section{Kaynaklar}

Bayrak, B. (2015). Ortaokul 8.sınıf öğrencilerinin üçgenler konusundaki matematiksel başarıları ile Van Hiele geometri düşünme düzeyleri ilişkisinin incelenmesi (Yayınlanmamış yüksek lisans tezi). Gazi Üniversitesi, Ankara.

Çelebi Akkaya, S. (2006). Van Hiele düzeylerine göre hazırlanan etkinliklerin ilköğretim 6.sınıf öğrencilerinin tutumuna ve başarısına etkisi (Yayınlanmamış yüksek lisans tezi). Abant İzzet Baysal Üniversitesi, Bolu.

Dağdelen, M. G. (2012). Illköğretim 5. sınıf geometri öğretiminde özel dörtgenlerin kavratılmasında origaminin etkisi (Yayınlanmamış yüksek lisans tezi). Ondokuz Mayıs Üniversitesi, Samsun.

Ferrance, E. (2000). Action research: themes in education. USA: Northeast and Islands Regional Educational at Brown University.

Güler, H. K. (2010). Karikatür kullanılarak yapılan öğretimin ilköğretim 6.sınıf öğrencilerinin matematik dersi doğal sayılar alt öğrenme alanındaki akademik başarılarına ve matematik dersine karşı tutumlarına etkisi (Yayınlanmamış yüksek lisans tezi). Gazi Üniversitesi, Ankara.

Gürbüz, T. (2015). $5 E$ öğrenme modeline uygun etkinliklerin ortaokul 1.sınıf öğrencilerinin matematik dersi kesirler konusundaki akademik başarılarına etkisi (Yayınlanmamış yüksek lisans tezi). Gazi Üniversitesi, Ankara.

Hurma, A. R. (2011). 9. sınıf geometri dersi çokgenler açı ünitesinde Van Hiele modeline dayalı ögrretimin öğrencinin problem çözme başarısına ve öğrenmenin kalıcılığına etkisi (Yayınlanmamış yüksek lisans tezi). Atatürk Üniversitesi, Erzurum.

İnce, H. (2012). Kırsal bölgelerde ve şehir merkezindeki öğrencilerin dönüşüm geometrisi anlama düzeylerinin ve uzamsal görselleştirme yeteneklerinin incelenmesi (Yayınlanmamış yüksek lisans tezi). Eskişehir Osmangazi Üniversitesi, Eskişehir.

Kaymakçı, Z. (2015). 5E öğrenme modeline göre hazırlanan etkinliklerin ortaokul 2.sınıf öğrencilerinin akademik başarılarına etkisi (Yayınlanmamış yüksek lisans tezi). Gazi Üniversitesi, Ankara.

Koçak, B. B. (2009). Süsleme etkinliklerinin ilköğretim 5.sınıf öğrencilerinin Van Hiele geometrik düşünme düzeylerine etkisi ( Yayınlanmamış yüksek lisans tezi). Eskişehir Osmangazi Üniversitesi, Eskişehir.

Kurak, Y. (2009). Dinamik geometri yazıımı kullanımının öğrencilerin dönüşüm geometri anlama düzeylerine ve akademik başarılarına etkisi (Yayınlanmamış yüksek lisans tezi). Karadeniz Teknik Üniversitesi, Trabzon. 
NCTM (2000). Principles and standards for school mathematics. Reston, VA: National Council of Teachers of Mathematics.

Soon, Y. P. (1989). An investigation on Van Hiele-like levels of learning transformation geometry of secondary school students in Singapore. Dissertation Abstract International, 50 (3), 619A.

Teltik Başer, E. (2008). 5E modeline uygun öğretim etkinliklerinin 7.sını öğrencilerinin matematik dersindeki akademik başarılarına etkisi (Yayınlanmamış yüksek lisans tezi). Gazi Üniversitesi, Ankara.

Tomooğlu, Ö. (2017). 6. sınıf öğrencilerine alan ölçme konusunun öğretimine yönelik bir eylem araştırması (Yayınlanmamış yüksek lisans tezi). Eskişehir Osmangazi Üniversitesi, Eskişehir.

Tuna, A. (2011). Trigonometri öğretiminde $5 E$ öğrenme döngüsü modelinin öğrencilerin matematiksel düşünme ve akademik başarılarına etkisi (Yayınlanmamış doktora tezi). Gazi Üniversitesi, Ankara.

Usiskin, Z. (1982). Van Hiele Levels and Achievement in Secondary School Geometry. University of Chicago.

Van de Walle, J. A., Karp, K. S., \& Bay-Williams, J. M. (2012). ilkokul ve ortaokul matematiği (S. Durmuş, Çev. Ed.). Ankara: Nobel.

Yıldırım, A. (2009). Euclidean reality geometri etkinliklerinin, işitme durumuna göre öğrencilerin Van Hiele geometri düzeylerine, geometri tutumlarına ve başarılarına etkisi (Yayınlanmamış yüksek lisans tezi). Eskişehir Osmangazi Üniversitesi, Eskişehir.

Yıldız, A. (2014). 5E öğrenme modeli döngüsünün 6.sınıf öğrencilerinin geometrik başarı ve Van Hiele geometrik düşünme düzeylerine etkisi (Yayınlanmamış yüksek lisans tezi). Gazi Üniversitesi, Ankara. 